medRxiv preprint doi: https://doi.org/10.1101/2021.08.15.21262067; this version posted August 20, 2021. The copyright holder for this preprint (which was not certified by peer review) is the author/funder, who has granted medRxiv a license to display the preprint in perpetuity.

It is made available under a CC-BY-NC 4.0 International license .

\title{
Significant reduction in humoral immunity among healthcare workers and nursing home residents 6 months after COVID-19 BNT162b2 mRNA vaccination
}

David H. Canaday ${ }^{1,2}$, Oladayo A. Oyebanji ${ }^{1}$, Debbie Keresztesy ${ }^{1}$, Michael Payne ${ }^{1}$, Dennis Wilk $^{1}$, Lenore Carias ${ }^{1}$, Htin Aung ${ }^{1}$, Kerri St. Denis ${ }^{3}$, Evan C. Lam ${ }^{3}$, Christopher F. Rowley ${ }^{4}$, Sarah D. Berry ${ }^{5}$, Cheryl M. Cameron ${ }^{1}$, Mark J. Cameron ${ }^{1}$, Brigid Wilson ${ }^{2,}$, Alejandro B. Balazs $^{3}$, Christopher L. King ${ }^{1}$, Stefan Gravenstein ${ }^{6,7}$

${ }^{1}$ Case Western Reserve University School of Medicine, Cleveland, $\mathrm{OH}$

${ }^{2}$ Geriatric Research, Education and Clinical Center, Cleveland VA

${ }^{3}$ Ragon Institute of MGH, MIT and Harvard, Cambridge, MA

${ }^{4}$ Division of Infectious Diseases, Beth Israel Deaconess Medical Center, Boston, MA

${ }^{5}$ Marcus Institute for Aging Research, Hebrew SeniorLife, Boston, MA.

${ }^{6}$ Division of Geriatrics and Palliative Medicine, Alpert Medical School of Brown University, Providence, RI

${ }^{7}$ Center on Innovation in Long-Term Services and Supports, Providence Veterans Administration Medical Center, Providence, RI

\section{Corresponding authors: David.Canaday@case.edu and Stefan_Gravenstein@brown.edu}

\begin{abstract}
High COVID-19 mortality among nursing home (NH) residents led to their prioritization for SARSCoV-2 vaccination; most NH residents received BNT162b2 mRNA vaccination under the Emergency Use Authorization due to first to market and its availability. With NH residents' poor initial vaccine response, the rise of $\mathrm{NH}$ breakthrough infections and outbreaks, characterization of the durability of immunity to inform public health policy on the need for boosting is needed. We report on humoral immunity from 2 weeks to 6-months post-vaccination in $120 \mathrm{NH}$ residents and 92 ambulatory healthcare worker controls with and without pre-vaccination SARS-CoV-2 infection. Anti-spike and anti-receptor binding domain (RBD) IgG, and serum neutralization titers, were assessed using a bead-based ELISA method and pseudovirus neutralization assay. Antispike, anti-RBD and neutralization levels dropped more than $84 \%$ over 6 months' time in all groups irrespective of prior SARS-CoV-2 infection. At 6 months post-vaccine, 70\% of the infection-naive $\mathrm{NH}$ residents had neutralization titers at or below the lower limit of detection compared to $16 \%$ at 2 weeks after full vaccination. These data demonstrate a significant reduction in levels of antibody in all groups. In particular, those infection-naive NH residents had lower initial post-vaccination humoral immunity immediately and exhibited the greatest declines 6 months later. Healthcare workers, given their younger age and relative good-health, achieved higher initial antibody levels and better maintained them, yet also experienced significant declines in humoral immunity. Based on the rapid spread of the delta variant and reports of vaccine breakthrough in $\mathrm{NH}$ and among younger community populations, boosting $\mathrm{NH}$ residents may be warranted.
\end{abstract}


medRxiv preprint doi: https://doi.org/10.1101/2021.08.15.21262067; this version posted August 20, 2021. The copyright holder for this preprint (which was not certified by peer review) is the author/funder, who has granted medRxiv a license to display the preprint in perpetuity.

It is made available under a CC-BY-NC 4.0 International license .

\section{Research Letter}

The very high overall COVID-19 morbidity and mortality among nursing home (NH) residents led to their prioritization for early vaccination. In the US, most NH residents received BNT162b2 mRNA vaccination both because of its earlier Emergency Use Authorization approval and availability. $\mathrm{NH}$ residents that never had SARS-CoV-2 infection before the time of the vaccination series produced $\sim 1 / 4$ the antibody to this vaccine than that produced by healthy younger individuals. ${ }^{1,2}$ With the rise of breakthrough infections in $\mathrm{NH}$ residents and others with immunocompromise, there is a significant need for characterization of the durability of immunity to inform public health policy. We report on 2week and 6-month post-vaccination antibody levels from $120 \mathrm{NH}$ residents (aged 48-100 years, median 76) and 91 ambulatory healthcare worker controls (aged 26-78 years, median 48) with and without SARS-CoV-2 infection prior to vaccination. We assessed anti-spike and anti-receptor binding domain (RBD) IgG, and serum neutralization titers, using a bead-based ELISA method and pseudovirus neutralization assay. ${ }^{1}$ Anti-spike, anti-RBD and neutralization geometric mean levels dropped more than $84 \%$ over 6 months' time in all groups (Fig. 1a-c) irrespective of prior SARSCoV-2 infection. At 6 months post-vaccine, $70 \%$ of the infection-naive $\mathrm{NH}$ residents had neutralization titers at or below the lower limit of detection (LLD, 1:12 titer) compared to 16\% at the LLD at 2 weeks after full vaccination (Supplemental Table 1). Controls and NH residents who survived prior infection had $19 \%$ and $35 \%$ respectively at LLD at 6 months post-vaccination. These data demonstrate significant 6-month antibody decline in all groups.

An improved understanding of the clinical consequences of this drop in humoral immunity is urgently needed to optimally inform boosting strategies and policy that are being actively considered in the recent CDC recommendation. However, in the absence of clinical evidence, extrapolating from laboratory values may be necessary. $\mathrm{NH}$ residents and healthcare workers were amongst the earliest populations vaccinated in the US and elsewhere, resulting in the longest time for immunity to wane. In particular, those infection-naive $\mathrm{NH}$ residents had lower initial postvaccination humoral immunity immediately and exhibited the greatest declines 6 months later. Healthcare workers, given their younger age and relative good-health, achieved higher initial antibody levels and better maintained them, yet also experienced significant declines in humoral immunity. The rapid delta variant spread, vaccine breakthrough in NHs and community, ${ }^{3-5}$ and rapid antibody decline support CDC's recommended boosting $\mathrm{NH}$ residents to curb spread or prevent severe illness.

Supplemental Table 1. Proportion at the lower limit of detection (LLD, 1:12 titer) with pseudovirus neutralization assay (pNT50).

\begin{tabular}{lcccc} 
& $\begin{array}{c}\text { 2 weeks } \\
\text { post-vaccination }\end{array}$ & $\begin{array}{c}\text { Fisher's exact test } \\
\text { p-value }\end{array}$ & $\begin{array}{c}\mathbf{6} \text { months } \\
\text { post-vaccination }\end{array}$ & $\begin{array}{c}\text { Fisher's exact test } \\
\text { p-value }\end{array}$ \\
\hline Naïve & & & & \\
Control & $1 / 64(2 \%)$ & 0.005 & $10 / 64(16 \%)$ & $<0.001$ \\
NH resident & $11 / 73(16 \%)$ & & $51 / 73(70 \%)$ & \\
Prior infection & & & & \\
Control & $0 / 26$ & NS & $5 / 26(19 \%)$ & 0.19 \\
NH resident & $0 / 43$ & & $15 / 43(35 \%)$ & \\
\hline
\end{tabular}


medRxiv preprint doi: https://doi.org/10.1101/2021.08.15.21262067; this version posted August 20, 2021. The copyright holder for this preprint (which was not certified by peer review) is the author/funder, who has granted medRxiv a license to display the preprint in perpetuity.

It is made available under a CC-BY-NC 4.0 International license.

\section{References}

1. Canaday DH, Carias L, Oyebanji OA, et al. Reduced BNT162b2 mRNA vaccine response in SARS-CoV-2-naive nursing home residents. Clin Infect Dis 2021.

2. Muller L, Andree M, Moskorz W, et al. Age-dependent immune response to the Biontech/Pfizer BNT162b2 COVID-19 vaccination. Clin Infect Dis 2021.

3. Nanduri S PT, Derado G. Effectiveness of Pfizer-BioNTech and Moderna Vaccines in Preventing SARS-CoV-2 Infection Among Nursing Home Residents Before and During Widespread Circulation of the SARS-CoV-2 B.1.617.2 (Delta) Variant - National Healthcare Safety Network, March 1-August 1, 2021. MMWR Morbidity and mortality weekly report 2021.

4. Teran RA, Walblay KA, Shane EL, et al. Postvaccination SARS-CoV-2 Infections Among Skilled Nursing Facility Residents and Staff Members - Chicago, Illinois, December 2020-March 2021. MMWR Morbidity and mortality weekly report 2021;70:632-8.

5. Brown CM, Vostok J, Johnson H, et al. Outbreak of SARS-CoV-2 Infections, Including COVID-19 Vaccine Breakthrough Infections, Associated with Large Public Gatherings - Barnstable County, Massachusetts, July 2021. MMWR Morbidity and mortality weekly report 2021;70:1059-62. 
medRxiv preprint doi: https://doi.org/10.1101/2021.08.15.21262067; this version posted August 20, 2021. The copyright holder for this preprint (which was not certified by peer review) is the author/funder, who has granted medRxiv a license to display the preprint in perpetuity.

It is made available under a CC-BY-NC 4.0 International license.

Figure 1.

CONTROL

a

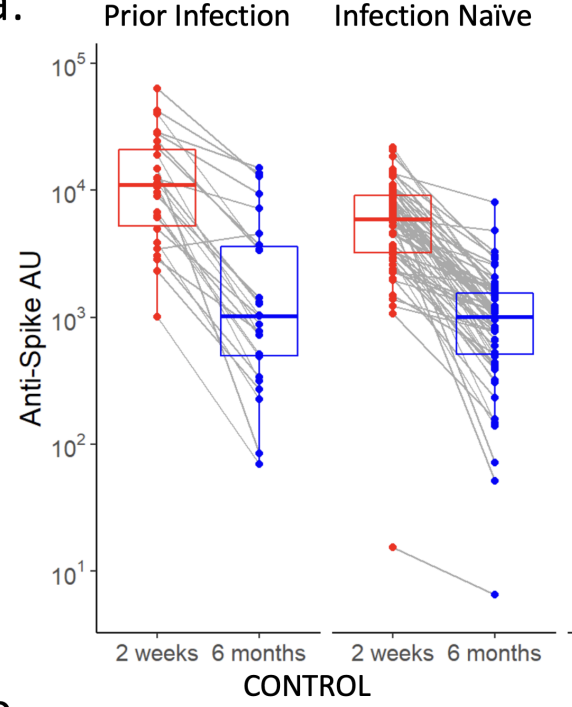

b.

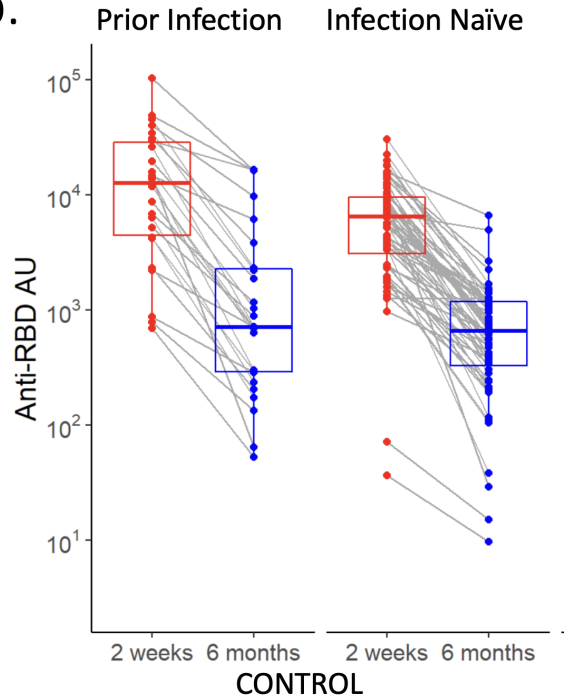

C.

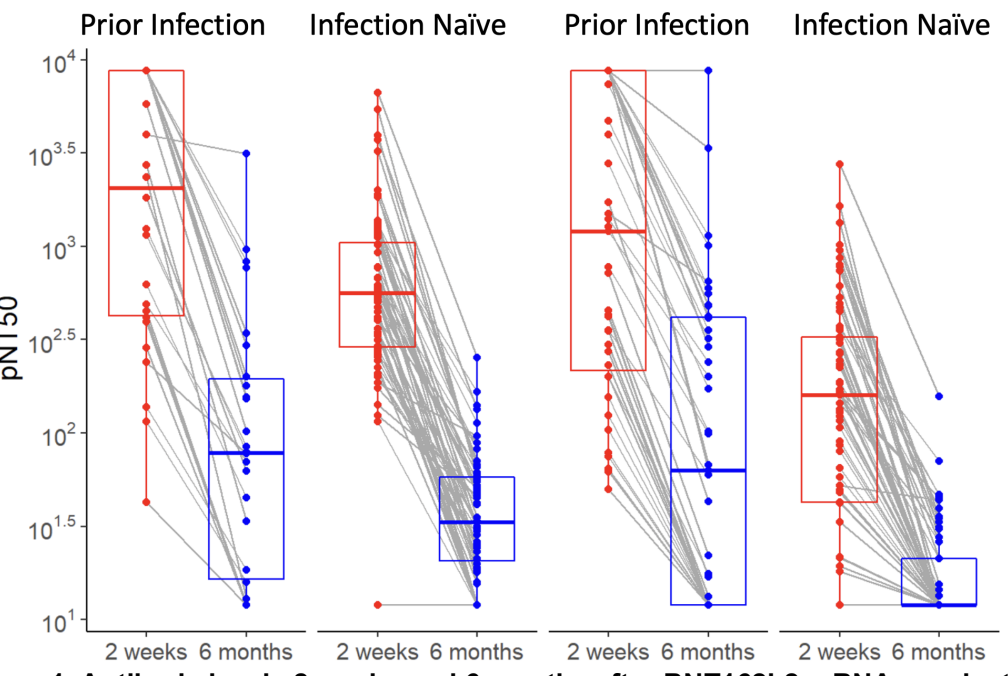

NURSING HOME RESIDENT

Prior Infection Infection Naïve

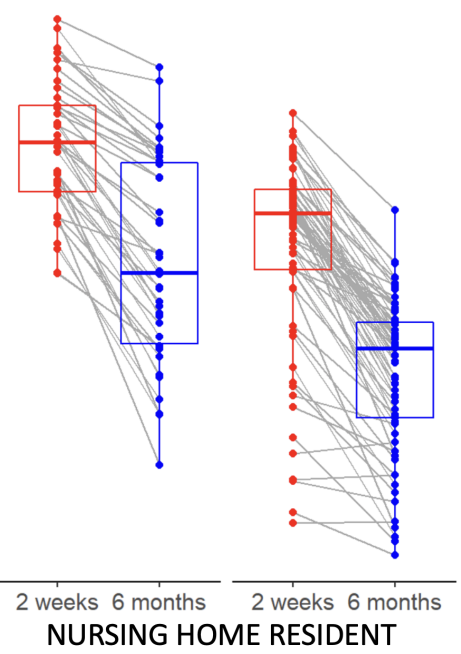

Prior Infection Infection Naïve

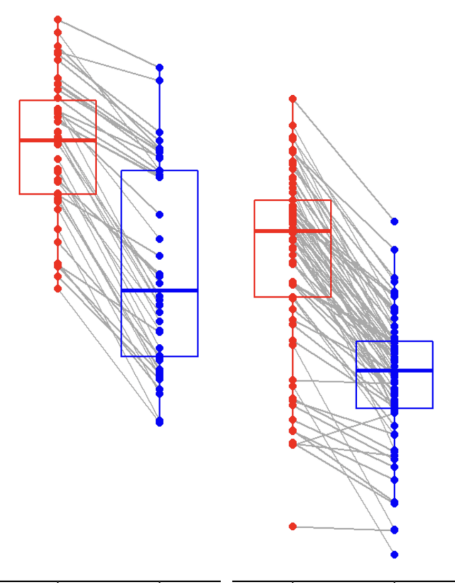

2 weeks 6 months 2 weeks 6 months NURSING HOME RESIDENT

Prior Infection Infection Naïve

Figure 1. Antibody levels 2 weeks and 6 months after BNT162b2 mRNA vaccination in healthcare workers and nursing home residents, with and without SARS-CoV-2 infection prior to vaccination. Post-vaccination anti-spike arbitrary units (AU) (Figure 1a.), anti-receptor binding domain (Figure 1b), and pseudovirus neutralization (pNT50) (Figure 1c) are shown. Residents refers to NH residents and Control refers to younger healthcare workers. Prior infection refers to antibody levels at the given time points in individuals vaccinated after recovering from earlier SARS-CoV-2 infection, and infection naive refers to individuals vaccinated without prior SARS-CoV-2 infection. Geometric means in each group were assessed using paired ttests of log-transformed values among subjects with both measures present. $P$ values comparing the difference between 2 weeks and 6 months in all clinical groups were $p<0.001$. Subjects with large increases $(>100 \%)$ of anti-spike, anti-RBD, or neutralizing titers from 2 weeks to 6 months were excluded due to presumed SARS-CoV-2 infection after vaccination. 